\title{
(Good) Land and Freedom (for Former Serfs): Determinants of Peasant Unrest in European Russia, March-October 1917
}

\author{
Evgeny Finkel, Scott Gehlbach and Dmitrii Kofanov
}

Peasant unrest was a key factor in the Russian Revolution. "In the revolutions of 1917 the role of the peasantry, the vast majority of the Russian population, was decisive. Without the simultaneous rising of the peasants, the workers' revolution could not have been accomplished," writes Orlando Figes. ${ }^{1}$ Notwithstanding the peasantry's key role, however, scholarly analysis of the Russian Revolution has traditionally focused on Russia's urban areas. As far as the much more numerous peasantry is concerned, the standard, longestablished contention is that peasant actions in 1917 were driven by two key factors-land and freedom (zemlia $i$ volia) - but there is no systematic statistical evidence to support (or reject) this view.

In this paper, we reexamine peasant unrest in the period from March to October 1917. We discuss and compare the two main sources of information on peasant disturbances, we illustrate geographic variation in the actions recorded by these sources, and we statistically identify determinants of this variation. We show that two factors robustly drive guberniia-level variation in peasant unrest in 1917: soil quality and the historical prevalence of serfdom. These results qualify the conventional view discussed above: it is good land, and arguably freedom for former serfs, that were decisive in 1917.

Our brief contribution to this special issue of the Slavic Review should be viewed as the start, not the end, of renewed quantitative research on the Russian countryside during the 1917 Revolution. Our analysis demonstrates the promises and challenges of using existing data on peasant unrest during the Revolution. It further highlights the need to understand the role of historical legacies of labor and political institutions, especially serfdom. Finally, and most generally, this essay illustrates the potential contributions of socialscientific method to our understanding of Russian history.

\section{Previous Work}

Although most analysis of the Russian Revolution tends to focus on cities at the expense of the countryside, several scholars have studied peasant behavior during the period between the two revolutions of 1917. Graeme Gill's analysis of rural Russia in 1917 is the exemplar of countrywide studies of the topic. ${ }^{2}$ Gill attempts to reconstruct the regional and temporal dynamics of peasant unrest, but his work suffers from several limitations. First, the

1. Orlando Figes, Peasant Russia, Civil War: The Volga Countryside in Revolution, (1917-1921) (Oxford, 1989), 30.

2. Graeme J. Gill, Peasants and Government in the Russian Revolution (New York, 1979). 
analysis is based on information collected by the Provisional Government. ${ }^{3}$ As we discuss below, data on peasant disturbances have been substantially expanded and updated since the publication of Gill's research. More importantly, Gill's analysis does not normalize disturbances by the size of the rural population in each guberniia, thus providing a biased picture of geographic variation in unrest. Finally, although Gill discusses the types and dynamics of peasant actions, his study does not identify the underlying causes of these disturbances. ${ }^{4}$

Recent decades have seen new interest in the experience of the Russian countryside during and after the revolutions of 1917, with important scholarly work focusing on the experience of specific regions. Analysis of the Volga countryside, for example, shows a very high degree of peasant unrest in Saratov guberniia, in contrast to the neighboring Don Host region, where disturbances were minimal-a pattern reflected in our data. ${ }^{5}$ Related work shows that land conflict was a key factor in the extensive peasant unrest in Kazan' and Nizhnii Novgorod guberniias; in neighboring Viatka, the land question was arguably unimportant. ${ }^{6}$

These region-level studies substantially improve our knowledge of local dynamics, but our general understanding of peasant unrest from March to October 1917 remains limited. We know little about the character and sources of variation in the intensity and types of peasant disturbances across different parts of the Empire. Indeed, as region-focused studies have highlighted differences in the causes and prevalence of peasant actions across Russia, there has emerged a growing need to incorporate local determinants into a countrywide analysis of peasant unrest in 1917. This is a primary goal of this article.

One important question in the literature is mostly beyond the scope of this short essay: the impact of previous waves of peasant unrest on disturbances in 1917. Various accounts of the Russian Revolution have tied its emergence and development to the Revolution of 1905; some even point to the importance of the Emancipation Reform of $1861 .^{7}$ Further motivating the latter hypothesis, recent work has shown that peasant disturbances in the 1850s and early

3. K. G. Kotel'nikov and V. L. Meller, eds., Krestianskoe dvizhenie v 1917 godu (Moscow, 1927).

4. But see Gill's Chapter 4 for a discussion of potential explanations for unrest dynamics and intensity. There, while not normalizing by population size, Gill does discuss the average land holding levels per guberniia.

5. Figes, Peasant Russia, Civil War; Peter Holquist, Making War, Forging Revolution: Russia's Continuum of Crisis, 1914-1921 (Cambridge, Mass., 2002).

6. See Chapter 7, "Water Is Yours, Light Is Yours, the Land Is Yours, the Wood Is Yours," in Sarah Badcock, Politics and the People in Revolutionary Russia: A Provincial History (Cambridge, Eng., 2007); Aaron B. Retish, Russia's Peasants in Revolution and Civil War: Citizenship, Identity, and the Creation of the Soviet State, 1914-1922 (New York, 2008). For the claim that peasant actions were driven by the land issue, see Rex A. Wade, The Russian Revolution, 1917 (New York, 2005), 129; John Channon, "The Peasantry in the Revolutions of 1917," in Edith Rogovin Frankel, Jonathan Frankel, and Baruch Knei-Paz, eds., Revolution in Russia: Reassessments of 1917 (New York, 1992), 105-30.

7. Sheila Fitzpatrick, The Russian Revolution (Oxford, 1994), 20-21; Orlando Figes, Revolutionary Russia, 1891-1991 (London, 2014), 11-12, 35-36, 79; Matthew Rendle, Defenders of the Motherland: The Tsarist Elite in Revolutionary Russia (Oxford, 2010); Channon, "The Peasantry in the Revolutions of 1917," 123. 
1860s were substantially more numerous in districts where serfdom was (had been) prevalent, and that emancipation itself provoked a substantial wave of peasant unrest. ${ }^{8}$ Given the possibility of lingering grievances from serfdom, as well as persistence in repertoires of collective action, we focus here on the legacy of serfdom as a potential determinant of unrest in 1917. Unfortunately, it is not straightforward to simultaneously explore the impact of unrest in the mid-nineteenth century or in 1905-7: in the jargon of econometrics, these variables are "post-treatment"-they are themselves potentially the outcome of serfdom. A complete analysis of intertemporal linkages in peasant unrest therefore must await future work.

\section{Measuring Peasant Unrest}

To measure peasant unrest during 1917, we utilize two related counts of peasant disturbances in fifty provinces of European Russia. The first are monthly tables compiled from bulletins issued by the statistical branch of the Information Bureau of the Chief Administration of Militia Affairs (Informatsionnyi Otdel Glavnogo Upravleniia po Delam Militsii), which was part of the Ministry of Interior of the Provisional Government (hereafter MIPG). ${ }^{9}$ The primary source of data for these bulletins was information on "notable" local incidents, provided by guberniia and uezd commissars of the Provisional Government and by private individuals and organizations..$^{10}$ Although the first reports arrived at the beginning of March, systematic collection of information for the bulletins started only in the second half of the month; the bulletins were daily only from April 14. Local reports were additionally supplemented-the tables indicate for July to September-by events culled from (apparently central) newspapers. ${ }^{11}$

Our second count of disturbances, Aleksandr Maliavskii's study (hereafter MAL), extends the data in MIPG to include October and substantially updates the data for 32 provinces for at least some months from March to September. ${ }^{12}$ According to Maliavskii, the data in MIPG give a skewed picture not only of the scope of the peasant movement in 1917 (which arguably was several times more intensive than portrayed), but also of its dynamics. ${ }^{13}$ His updates are based on multiple regional studies, published collections of documents, and some archival materials. Notably, it appears that the updates in MAL focus on provinces with more unrest: the average number of disturbances per capita

8. Paul Castañeda Dower, Evgeny Finkel, Scott Gehlbach, and Steven Nafziger, "Collective Action and Representation in Autocracies: Evidence from Russia's Great Reforms," (American Political Science Review, forthcoming); Evgeny Finkel, Scott Gehlbach, and Tricia D. Olsen, "Does Reform Prevent Rebellion? Evidence from Russia's Emancipation of the Serfs," Comparative Political Studies 48, no. 8 (July 2015): 984-1019.

9. Kotel'nikov and Meller, Krestianskoe dvizhenie.

10. Ibid., xvii-xix.

11. Vladimir Buldakov, Krasnaia smuta: Priroda i posledstviia revoliutsionnogo nasiliia (Moscow, 2010), 617.

12. Aleksandr Maliavskii, Krest'ianskoe dvizhenie v Rossii v 1917 g.: Mart-oktiabr' (Moscow, 1981).

13. Ibid., 378. 
in MIPG is roughly twice as great in provinces that are updated than in those that are not.

MIPG and MAL both provide counts of the total number of disturbances over the relevant period (March-September for MIPG, March-October for MAL). ${ }^{14}$ Each also breaks out disturbances by month, though MAL sometimes provides aggregate figures for two or more months, and as noted above MIPG appears to use additional sources for July-September (only). Finally, MIPG disaggregates monthly disturbances by type (such as seizure of estates and illegal cutting of timber), though with substantial inconsistency across months.

As discussed above, scholars of the Russian Revolution have used both counts, each of which has advantages and disadvantages. MIPG applies a more-or-less common methodology across regions, but it is particularly incomplete for the early months, and it relies primarily upon the reports of commissars and private persons or organizations (usually victims of these disturbances), as well as on some information from newspapers. MAL, in contrast, incorporates a much broader range of sources (the average number of peasant disturbances per 100,000 rural residents is roughly three times greater in MAL than in MIPG), but it updates event counts for MarchSeptember for only some provinces, and it frequently aggregates disturbances across two or more months. ${ }^{15}$

In this paper, rather than adjudicating between the two counts, we use both. Confidence in our results should be greater, to the extent that we identify determinants of peasant unrest that are independent of the data source. Given the issues with monthly dynamics in each source, we focus exclusively on aggregate counts of disturbances from March to September/October. Table 1 provides summary statistics for these and other variables.

\section{Spatial Patterns of Peasant Unrest}

Figures 1 and 2 illustrate spatial variation in peasant unrest as measured by the two data sources described above. For both MIPG and MAL, disturbances are generally more prevalent in the agricultural center of European Russia than at the periphery. MIPG also documents substantial unrest in a band of provinces that runs east of the 1917 front line and west of Moscow.

What explains these spatial patterns? We focus especially on two potential determinants of unrest that are discussed in the literature summarized above. First, given that land conflict was at the center of revolutionary activity in the Russian countryside in 1917, we examine whether disturbances may have been more numerous in regions with relatively fertile soil. Following Finkel, Gehlbach, and Olsen, we derive a measure of soil fertility from GIS-coded data

14. We use only MIPG data on "land-related offences” (zemel'nye pravonarusheniia). Other categories included in the monthly tables are either not directly relevant to the peasant movement, such as worker, trade, and military disturbances, or combine urban and rural incidents, as in case of the "pogrom movement" (pogromnoe dvizhenie) and "pogrom-seizure offences" (pogromno-zakhvatnye pravonarusheniia). MAL similarly uses MIPG data on "land-related offences" as a baseline.

15. The pairwise correlation between the two measures is 0.52 . 
Table 1

Summary Statistics

\begin{tabular}{|c|c|c|c|c|c|}
\hline Variable & Observations & Mean & $\begin{array}{l}\text { Standard } \\
\text { deviation }\end{array}$ & Minimum & Maximum \\
\hline Disturbances per 100,000 rural residents, March to Sept 1917 (MIPG) & 50 & 2.985 & 2.376 & 0 & 11.104 \\
\hline Disturbances per 100,000 rural residents, March to Oct 1917 (MAL) & 50 & 13.413 & 15.322 & 0 & 62.044 \\
\hline Estate seizures per 100,000 rural residents, April to Sept 1917 (MIPG) & 50 & 0.633 & 0.605 & 0 & 3.116 \\
\hline Other seizures per 100,000 rural residents, April to Sept 1917 (MIPG) & 50 & 1.203 & 1.072 & 0 & 4.645 \\
\hline Compulsory land rental per 100,000 rural residents, April to Sept 1917 (MIPG) & 50 & 0.054 & 0.089 & 0 & 0.475 \\
\hline Disruption of activities per 100,000 rural residents, April to Sept 1917 (MIPG) & 50 & 0.357 & 0.323 & 0 & 1.574 \\
\hline Other disturbances per 100,000 rural residents, April to Sept 1917 (MIPG) & 50 & 0.591 & 0.445 & 0 & 2.001 \\
\hline Fertile soil & 50 & 0.423 & 0.352 & 0.025 & 0.957 \\
\hline Serfdom & 50 & 0.403 & 0.251 & 0 & 0.896 \\
\hline Occupied & 50 & 0.160 & 0.370 & 0 & 1 \\
\hline Updated data & 50 & 0.640 & 0.485 & 0 & 1 \\
\hline
\end{tabular}




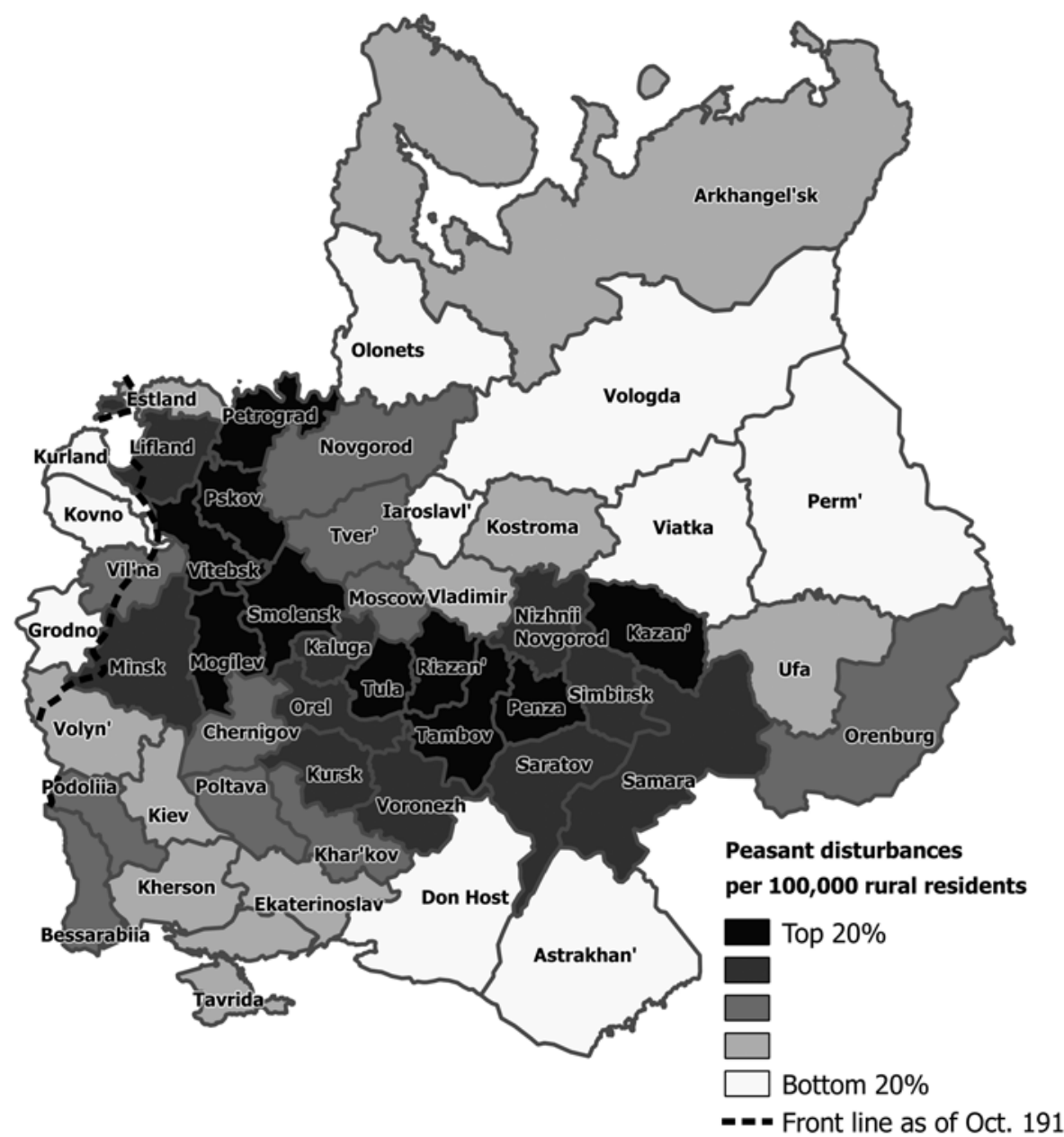

Figure 1. Peasant unrest from March to September 1917 according to data compiled by the Provisional Government.

on soil type from the Food and Agriculture Organization (FAO). ${ }^{16}$ Although the FAO data are from 1990, the passage of seventy years has little impact on soil type, which evolves in geologic time.

Second, given the historical association between serfdom and peasant unrest, and the likelihood that both grievances and repertoires of contention may have survived emancipation, we examine whether unrest was greater in regions in which serfdom was more prevalent. Using data from Artur Bushen, we compute the proportion of the rural population in 1858 who were either field or household serfs. ${ }^{17}$

16. Finkel, Gehlbach, and Olsen, "Does Reform Prevent Rebellion?”

17. Tsentral'nyi statisticheskii komitet, Statisticheskiia tablitsy rossiiskoi imperii za 1858 god: Nalichnoe naselenie imperii, Artur Bushen, ed., (St. Petersburg, 1863), available 


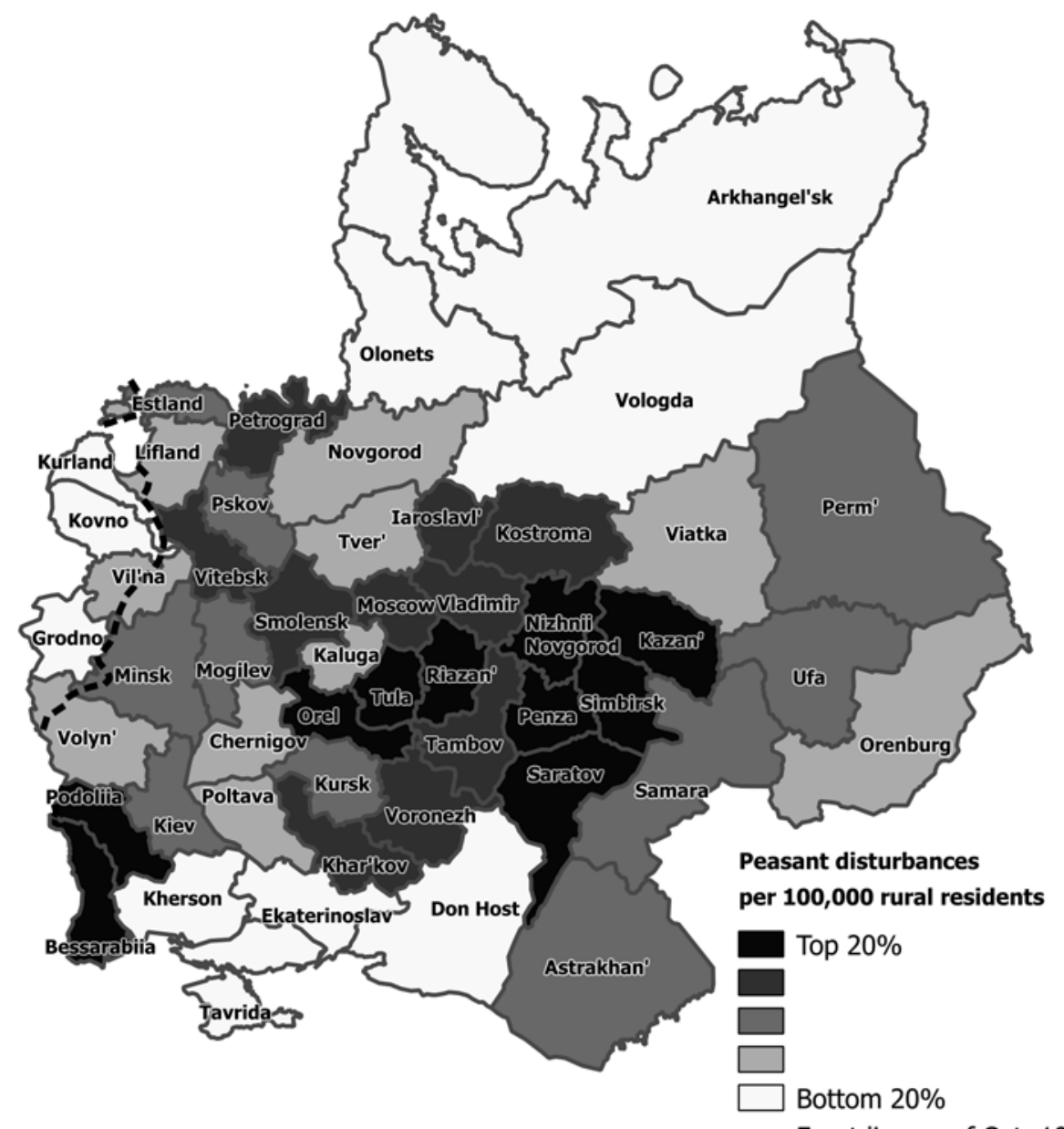

-- Front line as of Oct. 1917

Figure 2. Peasant unrest from March to October 1917 according to data compiled by Maliavskii (1981).

Figure 3 presents scatterplots of peasant unrest, as measured by both MIPG and MAL, and soil fertility and serfdom. As illustrated by the linear fit of the data in each plot, peasant disturbances in 1917 are more frequent in regions with relatively good soil and in regions where serfdom was prevalent prior to emancipation. The slope of the linear fit is least pronounced in the top-left panel, reflecting a weaker relationship between unrest and soil fertility when the former variable is measured using data from the Provisional Government.

In principle, the bivariate relationships illustrated in Figure 3 may be spurious, as other factors may drive both peasant unrest and soil fertility / serfdom. To more systematically examine the relationship between peasant unrest, on the one hand, and soil fertility and the historical legacy of serfdom,

at https://books.google.com/books?id=bltKAAAAYAAJ\&printsec=frontcover\&source= gbs_ge_summary_r\&cad=0\#v=onepage\&q\&f=false (last accessed August 5, 2017). 


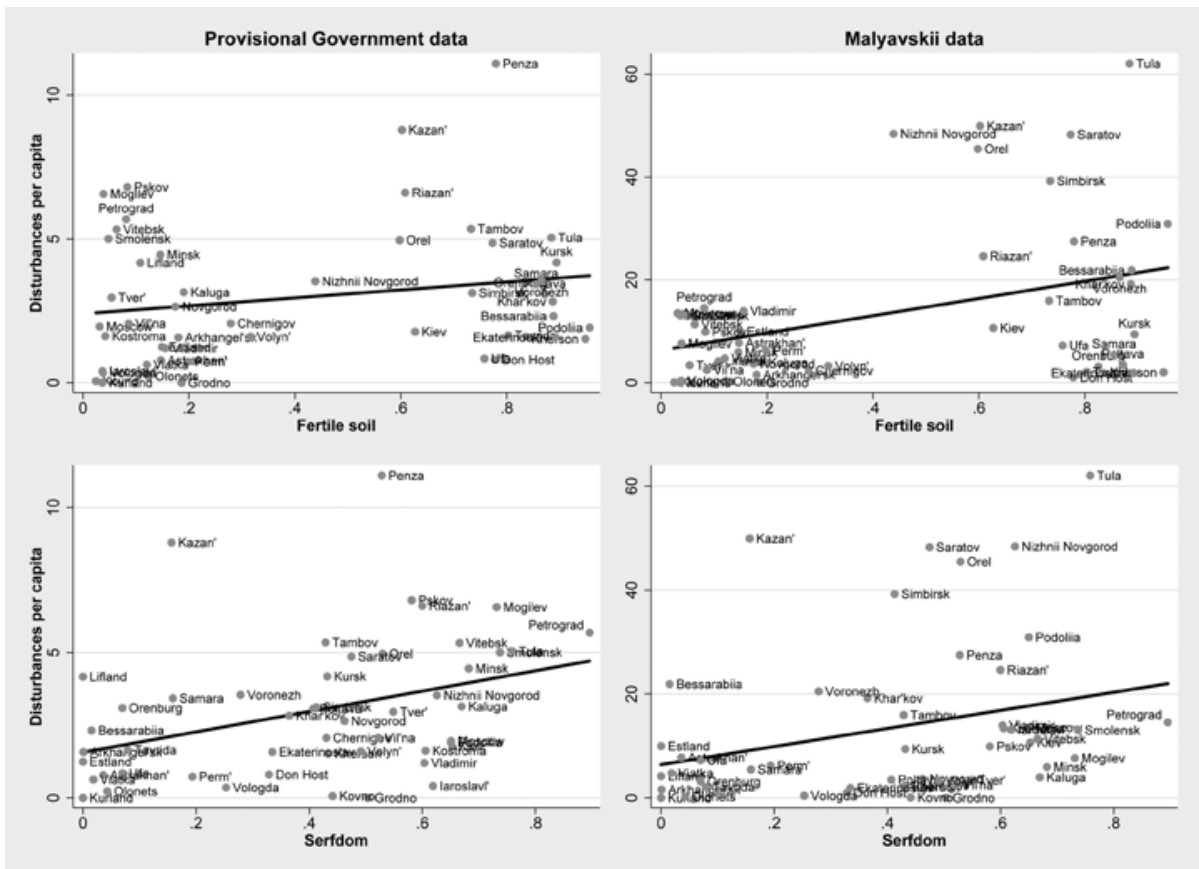

Figure 3. Bivariate relationship between a) fertile soil or serfdom and b) peasant unrest according to data compiled by the Provisional Government and Maliavskii (1981), respectively.

on the other, we turn to regression analysis. Various issues complicate our ability to identify the effect of land quality and legacy of serfdom on unrest in 1917. First, as reported above, the data-generating process is substantially different for MIPG and MAL. We therefore report results using each count as dependent (explained) variable. We also report results from regressions that include a dummy variable that takes a value of one if disturbances for MarchSeptember were updated by MAL. ${ }^{18}$

Second, regions under German occupation in 1917 may not only have experienced different levels of unrest, but Russian authorities' ability to observe this unrest may have been compromised. We address this concern by including in all regressions a dummy variable that takes a value of one if the province was partially or completely under German occupation in 1917. The affected provinces are Estland, Lifland, Kurland, Kovno, Vilna, Grodno, Minsk, and Volyn'.

Finally, unobserved determinants of reported unrest may be spatially correlated-what drives unrest in Tambov, or reports thereof, may be similar to that in Penza. We address this last concern by estimating two separate

18. As discussed above, provinces with more disturbances in MIPG are more likely to have been updated by MAL, implying that our indicator for updated data is likely endogenous to unrest. Results from regressions with this variable should therefore be treated with caution. 
"spatial error" models. ${ }^{19}$ We report results using both a "contiguity" weighting matrix that assumes similarity among immediate neighbors only-Tambov and Penza but not Tambov and Simbirsk-and an "inverse distance" weighting matrix that assumes that provinces that are geographically less distant are more similar than those that are further away. ${ }^{20}$

Table 2 presents results from regressions of unrest, as measured by MIPG and MAL, on the variables discussed above. Columns 1-3 and 4-6, respectively, represent the two versions of the spatial-error model. Land quality and the historical prevalence of serfdom are both significant predictors of unrest in 1917 in most regressions; each loses statistical significance in one regression employing an inverse-distance weighting matrix. (To understand the magnitude of these results, consider Column 1: a one-standard-deviation increase in either soil fertility or serfdom is associated with an increase in disturbances of approximately one-third of a standard deviation.) Notably, across all specifications and for both measures of unrest, there is no significant association between disturbances and whether a province was occupied by the German Army in 1917.

These results illustrate the importance of both land quality and historical experience in 1917. Unrest was greater in provinces with relatively good soil, where the economic value of the land was higher and the importance of agriculture (as opposed to crafts or foraging) for peasant livelihood was greater: there was simply more to fight for. Historically, the pattern is not uniquethere was also a strong correlation between land quality and peasant unrest during the period of Russia's Great Reforms..$^{21}$

Nonetheless, the manner in which the disturbances were carried out, including such "extra-lethal violence" as mutilation of bodies and desecration of graves, suggests that not only material motives were at play. ${ }^{22}$ For those who lived on former serf estates, the manor house was "a symbol of political, economic, and social oppression." ${ }^{23}$ Former state peasants, in contrast, "who did not have a single individual on whom to focus their aggression, waited for land reforms, rather than autonomously seizing land."24 "Freedom" may have meant something different in 1917 to the descendants of serfs than it did to other peasants.

Apart from emotion-based resentment against historical oppressors, peasant-landlord tensions were a constant feature of the post-emancipation countryside in former serf regions. The abolition of serfdom led to a partitioning of former estate lands into the landlords' private property and peasants'

19. That is, we estimate models with spatial-autoregressive "disturbances," though the latter term risks confusion in our empirical context.

20. We implement these models with the spreg package in Stata, estimating parameters by generalized spatial two-stage least squares and allowing for heteroskedastic disturbance terms.

21. Finkel, Gehlbach, and Olsen, "Does Reform Prevent Rebellion?"

22. Douglas Smith, Former People: The Final Days of the Russian Aristocracy (New York, 2012), 105-7; Figes, Peasant Russia, Civil War, 54; Lee Ann Fujii, "The Puzzle of Extra-Lethal Violence," Perspectives on Politics 11, no. 2 (June 2013): 410-26.

23. Rendle, Defenders of the Motherland, 85.

24. Retish, Russia's Peasants in Revolution and Civil War, 14, 96. 
Table 2

Determinants of Peasant Unrest

\begin{tabular}{|c|c|c|c|c|c|c|}
\hline & (1) & (2) & (3) & (4) & (5) & (6) \\
\hline & \multicolumn{3}{|c|}{ Contiguity matrix } & \multicolumn{3}{|c|}{ Inverse-distance matrix } \\
\hline & MIPG & MAL & MAL & MIPG & MAL & MAL \\
\hline Fertile soil & $\begin{array}{l}2.272^{\star \star} \\
(1.064)\end{array}$ & $\begin{array}{l}19.438^{\star \star \star} \\
(6.805)\end{array}$ & $\begin{array}{l}18.354^{\star \star \star} \\
(5.477)\end{array}$ & $\begin{array}{c}0.868 \\
(1.059)\end{array}$ & $\begin{array}{l}16.594^{\star \star} \\
(6.734)\end{array}$ & $\begin{array}{l}14.539 \star \star \\
(5.816)\end{array}$ \\
\hline Serfdom & $\begin{array}{l}3.066^{\star \star} \\
(1.204)\end{array}$ & $\begin{array}{l}20.746^{\star \star \star} \\
(7.266)\end{array}$ & $\begin{array}{l}16.413^{\star \star} \\
(6.672)\end{array}$ & $\begin{array}{l}3.791^{\star \star \star} \\
(1.198)\end{array}$ & $\begin{array}{l}19.374^{\star \star \star} \\
(6.948)\end{array}$ & $\begin{array}{l}11.653 \\
(8.123)\end{array}$ \\
\hline Occupied & $\begin{array}{r}-0.678 \\
(0.825)\end{array}$ & $\begin{array}{r}-0.556 \\
(3.632)\end{array}$ & $\begin{array}{c}2.868 \\
(3.829)\end{array}$ & $\begin{array}{r}-0.922 \\
(1.092)\end{array}$ & $\begin{array}{c}-5.121 \\
(3.590)\end{array}$ & $\begin{array}{c}0.134 \\
(4.391)\end{array}$ \\
\hline Updated data & & & $\begin{array}{l}11.696^{\star \star \star} \\
(2.898)\end{array}$ & & & $\begin{array}{l}16.819 \star \star \star \\
(2.831)\end{array}$ \\
\hline Constant & $\begin{array}{c}0.823 \\
(0.778)\end{array}$ & $\begin{array}{l}-3.329 \\
(4.464)\end{array}$ & $\begin{array}{l}-9.242^{\star \star} \\
(4.353)\end{array}$ & $\begin{array}{c}1.274 \\
(0.821)\end{array}$ & $\begin{array}{r}-0.593 \\
(6.008)\end{array}$ & $\begin{array}{r}-8.099 \\
(4.932)\end{array}$ \\
\hline $\begin{array}{l}\text { Spatial disturbance } \\
\text { parameter }(\rho)\end{array}$ & $\begin{array}{l}0.095^{\star \star \star} \\
(0.028)\end{array}$ & $\begin{array}{l}0.081^{\star \star} \\
(0.033)\end{array}$ & $\begin{array}{c}0.045 \\
(0.039)\end{array}$ & $\begin{array}{l}0.353^{\star} \\
(0.190)\end{array}$ & $\begin{array}{l}0.291^{\star \star} \\
(0.144)\end{array}$ & $\begin{array}{c}0.129 \\
(0.185)\end{array}$ \\
\hline
\end{tabular}

Notes: Spatial-error models with weighting matrixes as indicated. Heteroskedasticity-robust standard errors in parentheses. ${ }^{\star \star \star} \mathrm{p}<.01,{ }^{\star \star} \mathrm{p}<.05$, ${ }^{\star} \mathrm{p}<.10$. 
communal property-a process in which the landlords tended to keep the best land for themselves. In addition, land was often divided such that landlords' and peasants' land holdings were highly intertwined, thus increasing the potential for conflict and forcing peasants to rent land (often paid by work on the landlords' "demesne") at disadvantageous rates. ${ }^{25}$ Problems with such formerly common resources as forests, pastures, and meadows were even more acute: after emancipation, peasants had to pay for access, if such use was allowed at all.

These conflicts, common during the post-emancipation era, intensified during the Great War. Given labor shortages caused by the draft, peasants were unwilling to rent land at pre-war rates. In addition, the surging demand for fuel led to more intensive exploitation of forests by their owners, which made them less accessible to peasants. ${ }^{26}$ When the opportunity arose in 1917, tension turned into unrest.

As discussed above, MIPG disaggregates monthly totals for peasant unrest into several categories, though not always in a consistent manner, and often only from April. We are able to derive counts of disturbances for five categories of unrest that are reported for all (relevant) months from April to September. ${ }^{27}$ These include: seizure of estates (estate seizures); seizure of meadows, forests, tools, and harvests (other seizures); forced rental of landowners' land (compulsory land rental); obstruction of timber harvesting in forests not owned by peasants and forced removal of hired labor, prisoners of war, and refugees from agricultural activities (disruption of activities); and various unclassified disturbances (other).

In Figure 4, we report results from regressions for each of these five classes of disturbances. Each row presents results from a single regression analogous to that in Column 1 ("Model 1") and Column 4 ("Model 2") of Table 2. A few patterns emerge from this analysis: estate seizures are more common in regions with fertile soil (with "Model 2" just insignificant at a significance level of 0.05 ), and other seizures are more common in regions in which serfdom was historically prevalent. Obstruction of timber harvesting and forced removal of competing labor (that is, "disruption of activities"-often a prelude to land seizure), in turn, is clearly greater in regions with a legacy of serfdom..$^{28}$

Looking across all variables and models, however, the relationship between peasant unrest and soil fertility / serfdom is less pronounced than in the analysis of aggregate data. Most likely, peasants responded to idiosyncratic local considerations in deciding, for example, whether to seize meadows and forests or force the renting of land they did not own. Good land and freedom for former serfs drove unrest in 1917, though in different ways in different regions.

In interpreting these results, it is important to note that peasant-landlord conflicts were not the only type of violence in provincial Russia in 1917. In particular, our data do not address ethnic violence, which was a common

25. Aleksandr Engel'gardt, Iz derevni. 12 pisem. 1872-1887 (Moscow, 1956), 282.

26. Maliavskii, Krest' ianskoe dvizhenie v Rossii v 1917 g.: Mart-oktiabr', 166-67.

27. Harvest seizures are reported only for the harvest months of July, August, and September.

28. On the sequence of events leading to land seizure, see Maliavskii, Krest'ianskoe Dvizhenie v Rossii v 1917 g.: Mart-oktiabr', 93. 


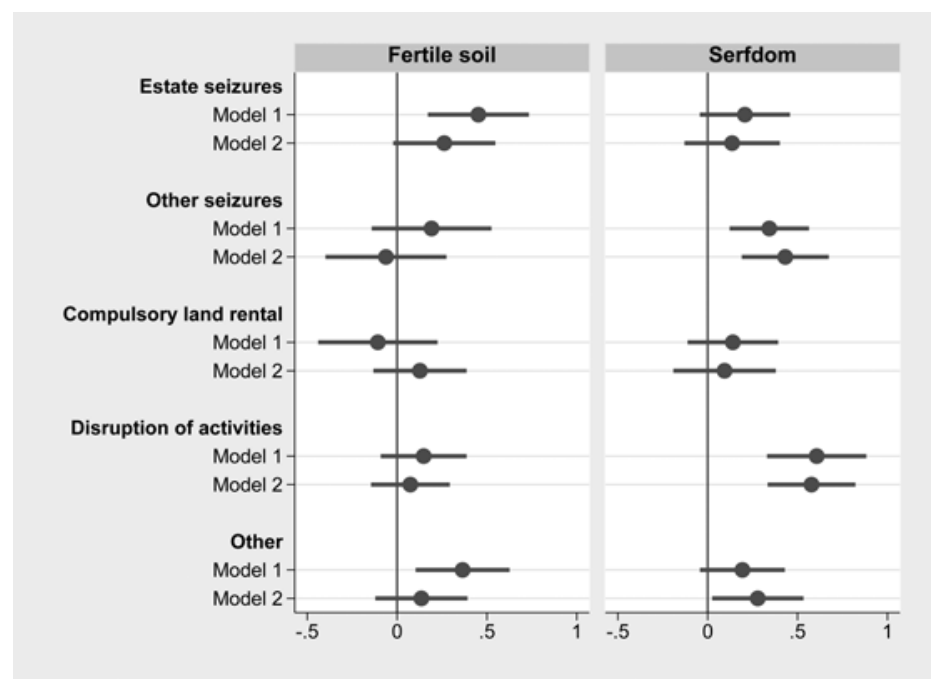

Figure 4. Estimated effect of soil fertility and historical prevalence of serfdom on various categories of peasant unrest, using data compiled by the Provisional Government. Each row presents results from a separate regression, corresponding to Column 1 ("Model 1") and Column 4 ("Model 2") in Table 2. Dots represent point estimates and lines represent 95-percent confidence intervals, such that lines that do not cross zero indicate statistical significance at the 5-percent level.

feature of the Civil War, especially in Ukraine. Thus, while MAL indicates that Podoliia had substantial peasant unrest in 1917, and historical accounts clearly demonstrate that the region experienced many anti-Jewish pogroms during the Civil War, our work does not allow us to draw any conclusions about possible connections between the two types of violence-a rich topic for future research.

In this essay, we examine spatial patterns of peasant unrest in European Russia during the period from the first to second revolution of 1917-a crucial but largely overlooked component of the Russian Revolution. We critically compare the two available sources of information on the peasant movement in 1917, and we illustrate the geographic variation in per-capita disturbances during this period. We also provide the first econometric analysis of peasant disturbances during the Russian Revolution, identifying two determinants of variation in peasant unrest: good soil and the historical prevalence of serfdom.

The results of our analysis qualify the traditional view that peasant actions in 1917 were driven by the desire for "land and freedom." Land, we show, was indeed crucial, but it was only good land that mattered, and freedom may have meant different things to former serfs and their descendants than it did to other peasants.

Our statistical analysis is only a first step toward renewed understanding of peasant unrest in 1917. Further work can provide a more detailed picture of these crucial events. 